\title{
Anti-CD95 (APO-1/Fas) autoantibodies and T cell depletion in human immunodeficiency virus Type 1 (HIV-1)-infected children
}

\author{
Kirstin Stricker, ${ }^{1,5}$, Eckart Knipping ${ }^{2,5}$, Thomas Böhler ${ }^{1}$, \\ Axel Benner ${ }^{3}$, Peter H. Krammer ${ }^{2}$ and \\ Klaus-Michael Debatin ${ }^{1,4}$ \\ 1 Haematology/Oncology, University Children's Hospital and Division of \\ Molecular Oncology, German Cancer Research Center, Heidelberg, Germany \\ 2 Tumorimmunology Program/Division of Immunogenetics, German Cancer \\ Research Center, Heidelberg, Germany \\ 3 Department of Biostatistics, German Cancer Research Center, Heidelberg, \\ Germany \\ 4 corresponding author: Dr. Klaus-Michael Debatin, University Children's \\ Hospital, Prittwitzstraße 43, D-89075 Ulm, Germany. tel: +49-731-502 7701; \\ fax: +49-731-502 6681 \\ 5 both authors contributed equally to this work
}

Received 23.6.97; revised 28.8.97; accepted 24.9.97

Edited by M.L. Gougeon

\begin{abstract}
Advanced stages of HIV-1-infection are characterized by progressive $\mathrm{CD}^{+} \mathrm{T}$ cell depletion. Peripheral T cells from HIV$1^{+}$donors show accelerated apoptosis in vitro. The CD95 (APO-1/Fas) receptor/ligand system is involved in this process. To further study deregulation of the CD95 system in peripheral $T$ cells during HIV-1-infection, we measured CD95-expression on $\mathrm{CD}^{+}$and $\mathrm{CD}^{+} \mathrm{T}$ cells together with serum levels of soluble CD95 (sCD95) and anti-CD95 autoantibodies in HIV-1 ${ }^{+}$children and healthy controls. AntiCD95 levels in HIV $-1^{+}$children were significantly elevated when compared to uninfected controls, whereas serum levels of SCD95 were not different. In HIV-1 ${ }^{+}$children, CD95expression on $\mathrm{CD} 4^{+}$and $\mathrm{CD} 8^{+} \mathrm{T}$ cells increased with age. $\mathrm{A}$ strong correlation between depletion of $\mathrm{CD} 4^{+}$cells in vivo and increase in CD95-expression on $\mathrm{CD}^{+} \mathrm{T}$ cells was observed. In contrast, such a correlation was not found for $C D 8^{+} T$ cells. A negative correlation between anti-CD95 autoantibody levels and $\mathrm{CD}^{+} \mathrm{T}$ cell counts, that was predicted by multiple linear regression analysis of pooled data, was found in individual patients observed longitudinally by repeated measurements. Since anti-CD95 autoantibodies isolated from HIV-infected adults have previously been shown to induce apoptosis of sensitive target cells in vitro, we speculate that the interaction of these antibodes with CD95-positive and CD95-sensitive T cells in vivo might be involved in progressive $T$ cell loss during HIV-1-infection.
\end{abstract}

Keywords: CD95(APO-1/Fas); soluble CD95; autoantibodies; $\mathrm{HIV}$; children; $\mathrm{CD}^{+}{ }^{+} \mathrm{T}$ cell depletion

Abbreviations: AICD, activation-induced cell death; AZT, Zidovudine; BSA, bovine serum albumin; CD95, CD95 receptor; CD95-L, CD95-ligand; sCD95, soluble CD95; HIV-1, human immunodeficiency virus type $1 ; \mathrm{HIV}-1^{+}, \mathrm{HIV}-1$-infected; HRPO, horseradish peroxidase; Ig, immunoglobulin; PAGE, polyacrylamide gel electrophoresis; PBS, phosphate buffered saline; SDS, sodium dodecyl sulfate; TCR, T cell receptor

\section{Introduction}

HIV-1 infection is characterized by progressive depletion of $\mathrm{CD}^{+}{ }^{+} \mathrm{T}$ lymphocytes. The molecular mechanism of $\mathrm{T}$ cell depletion in vivo is poorly defined. Recent experimental evidence suggests that depletion of $\mathrm{CD}^{+} \mathrm{T}$ cells is mediated via apoptosis (for review see Gougeon 1995; Oyaizu and Pahwa, 1995). T cells from $\mathrm{HIV}^{+}$donors have been shown to undergo increased spontaneous and activation-induced apoptosis in vitro (Meyaard et al, 1992; Groux et al, 1992) and in vivo (Finkel et al, 1995). Increased susceptibility to activation-induced cell death (AICD) of peripheral blood T cells correlates with disease progression in HIV-infected adults (Gougeon et al, 1996).

It has recently been shown that TCR-induced AICD involves autocrine CD95 (APO-1/Fas) receptor/ligand (L)mediated suicide (Dhein et al, 1995; Ju et al, 1995; Alderson et al, 1995). The CD95 (APO-1/Fas) receptor (CD95) is a member of the tumor necrosis factor/nerve growth factor (TNF/NGF) receptor superfamily and triggers apoptosis in peripheral T cells (Oehm et al, 1992; Itoh et al, 1991). CD95 is not expressed on the majority of naive resting $T$ cells in cord blood and shows only low expression on resting adult $\mathrm{T}$ cells (Klas et al, 1993; Miyawaki et al, 1992). Expression is increased after activation in vitro (Klas et al, 1993). Agonistic anti-CD95 antibodies induce apoptosis in activated but not resting peripheral human $\mathrm{T}$ cells (Trauth et al, 1989; Yonehara et al, 1989).

We and others have provided ample experimental evidence for an involvement of the CD95 receptor/ligand system in $\mathrm{T}$ cell apoptosis in HIV-1-infected individuals (Debatin et al, 1994; Katsikis et al, 1995; Estaquier et al, 1995; Bäumler et al, 1996). In particular, we observed an increased expression of CD95 and CD95-L together with an increased sensitivity towards CD95-mediated apoptosis in freshly isolated $\mathrm{T}$ cells from $\mathrm{HIV}-1^{+}$children (Debatin et al, 1994; Bäumler et al, 1996). Since CD95-mediated apoptosis can be blocked by a soluble form of CD95 (Cheng et al, 1994) and elevated levels of soluble CD95 (sCD95) may block CD95-L function and apoptosis in patients with leukemias (Knipping et al, 1995), accelerated apoptosis of $\mathrm{T}$ cells in HIV-1 infection could either result from an increase in pro-apoptotic factors such as expression of CD95 and CD95-L (Bäumler et al, 1996) or from a decrease of apoptosis blockers such as SCD95.

In addition to $\mathrm{T}$ cell deficiency, HIV-1 infection is characterized by a profound dysregulation of the $B$ cell 
system (Fauci, 1988). Especially in HIV-infected children a constant polyclonal B cell activation may lead to B cell expansion and elevated Lg levels (Lane et al, 1985; Via and Shearer, 1989). The antibody response is not only directed against viral proteins, such as gp120, gp41 and p24, but also against self antigens such as CD4 and MHC (Golding et al, 1988; Via and Shearer, 1989; Muller et al, 1992). Antibodies against gp41 have been shown to crossreact with $\mathrm{MHC}$ class II antigens and crossreactivity has been explained by a sequence identity of seven aminoacids between gp41 and MHC class II molecules (Blackburn et al, 1991). Furthermore, gp120 has homologies to CD4 and MHC class I molecules and autoantibodies against both self proteins have been detected in sera from HIV-1 infected individuals (Zagury et al, 1993). Likewise, a sequence identity of eight aminoacids between the V3-loop of gp120 and the extracellular part of the CD95 receptor has been described (Szawlowski et al, 1993). Therefore, we reasoned that crossreactive antibodies directed against CD95 are generated during the immune response to HIV-1 and might contribute to disease progression by inducing apoptosis in CD95-positive and sensitive $T$ cells.

In order to evaluate the role of CD95 and SCD95, as well as anti-CD95 autoantibodies in disease progression in HIV-1infected children, we correlated CD95-expression on CD4 ${ }^{+}$ and $\mathrm{CD}^{+} \mathrm{T}$ cells with age and in vivo $\mathrm{CD} 4^{+} \mathrm{T}$ cell depletion by repeated measurements in a cohort of 44 children infected perinatally with HIV-1 and 44 age-matched healthy controls. In addition, we measured anti-CD95 autoantibodies and sCD95-levels in serum samples from these children. We found that CD95-expression in $\mathrm{CD}^{+} \mathrm{T}$ cells from $\mathrm{HIV}-1^{+}$ children increased with age and was strongly enhanced during disease progression (as indicated by decreasing $\mathrm{CD}^{+} \mathrm{T}$ cell counts). Mean serum levels of SCD95 were similar in $\mathrm{HIV}-1^{+}$and HIV $-1^{-}$children. Anti-CD95 autoantibody levels, however, were significantly elevated in sera from HIV-1-infected children and increased with disease progression (i.e., decreasing $\mathrm{CD} 4^{+} \mathrm{T}$ cell counts).

\section{Results}

\section{Validity of the anti-CD95 ELISA}

To obtain a rapid and reliable system for detection of antiCD95 autoantibodies in human sera we established a sensitive ELISA. A chimeric antibody containing the CD95 binding sites of the original murine anti-CD95 antibody (Trauth et al, 1989) was fused to a human Fc part and used as standard. Using this humanized anti-CD95 antibody the sensitivity of the ELISA was found to be $50 \mathrm{pg}(500 \mathrm{pg} /$ $\mathrm{ml}=\mathrm{OD}_{492}=0.25=25 \mathrm{U}$ ). The detection limit was not affected by addition of human control sera (data not shown). Due to the dilution used $(1: 100)$ the detection limit for anti-CD95 in human sera was $5 \mathrm{ng} /$ well $(50 \mathrm{ng} / \mathrm{ml})$. Immunoglobulin (lg) concentrations up to $50 \mathrm{mg} / \mathrm{ml}$ human $\mathrm{lg}$ did not change the ELISA results (data not shown). Control sera of age-matched healthy donors had an average level of $25 \mathrm{U} / \mathrm{ml}$. Intraassay variation was less than $7 \%$ and interassay variation was less than $16 \%$ (data not shown).

\section{Serum levels of anti-CD95 autoantibodies are increased in HIV-1-infected children}

Using the ELISA for detection of anti-CD95 autoantibodies we analyzed 218 serum samples from 44 HIV-1-infected and 37 serum samples from 16 uninfected controls. AntiCD95 autoantibody levels in sera of HIV-1-infected children (Median: $662 \mathrm{pg} / \mathrm{ml}$, interquartile range: 474 to $954 \mathrm{pg} / \mathrm{ml}$ ) were significantly higher than in the control group (Median: $460 \mathrm{pg} / \mathrm{ml}$, interquartile range: 342 to $740 \mathrm{pg} / \mathrm{ml}, \quad P=0.029$; Figure 1a). Sera from HIV-1 ${ }^{+}$ children contained anti-CD95 autoantibodies at concentrations up to $3500 \mathrm{pg} / \mathrm{ml}$. This difference between HIV-1 ${ }^{+}$ and $\mathrm{HIV}-1^{-}$children seen in pooled data remained statistically significant even after controlling for repeated measurements and patient age $(P=0.047)$. Longitudinal data-analysis from single patients with different patterns of disease progression showed an increase in anti-CD95 autoantibody levels with decreasing $\mathrm{CD}^{+} \mathrm{T}$ cell count in the rapid progressor (Figure 1c) and low anti-CD95 autoantibody levels with a stably high $\mathrm{CD}^{+}{ }^{+} \mathrm{T}$ cell count in the long-term-non progressor (Figure 1d).

To confirm the specificity of the results obtained by ELISA, purified recombinant CD95 (Knipping et al, 1995) was blotted to nitrocellulose membranes and detected by the chimeric humanized anti-CD95 antibody or by antiCD95 autoantibodies from ELISA-positive serum samples. One representative result is shown in Figure 2. Purified recombinant CD95 was used in all lanes. CD95 incubated with either medium or control serum gave no bands in the immunoblot (lanes 1 and 2). Serum of an HIV $-1^{+}$donor, previously shown to contain anti-CD95 autoantibodies by ELISA, was able to detect also purified recombinant CD95 (lane 3). Humanized anti-CD95 $(10 \mu \mathrm{g} / \mathrm{ml})$ was used as a positive control (lane 4). Samples containing anti-CD95 antibodies (lanes 3 and 4) detected CD95 bands of 48$52 \mathrm{kD}$ in monomeric form and bands of higher molecular weight (multimeric form), reflecting the known tendency of recombinant CD95 to form SDS-stable dimers and multimers (Oehm et al, 1992; Knipping et al, 1995). Thus, autoantibodies against CD95 recognize different native forms of the molecule.

\section{Levels of soluble CD95 in HIV-1-infected children are not increased}

All sera assayed for anti-CD95 autoantibodies were also tested for SCD95. As shown in Figure 1b, serum levels of sCD95 were slightly (but not statistically significantly) lower in the HIV $-1^{+}$group than in the control group.

\section{Anti-CD95 autoantibody levels do not reflect global B cell activation}

Increased levels of anti-CD95 autoantibodies may be a consequence of global polyclonal B cell stimulation. Therefore, we analyzed autoantibody levels in correlation to the total number of $B$ cells and to total serum $\lg (\lg G+\lg A+\lg M)$ in individual patients. No clear correlation between the number of $B$ cells and anti-CD95 autoantibodies was observed (Figure 
a)

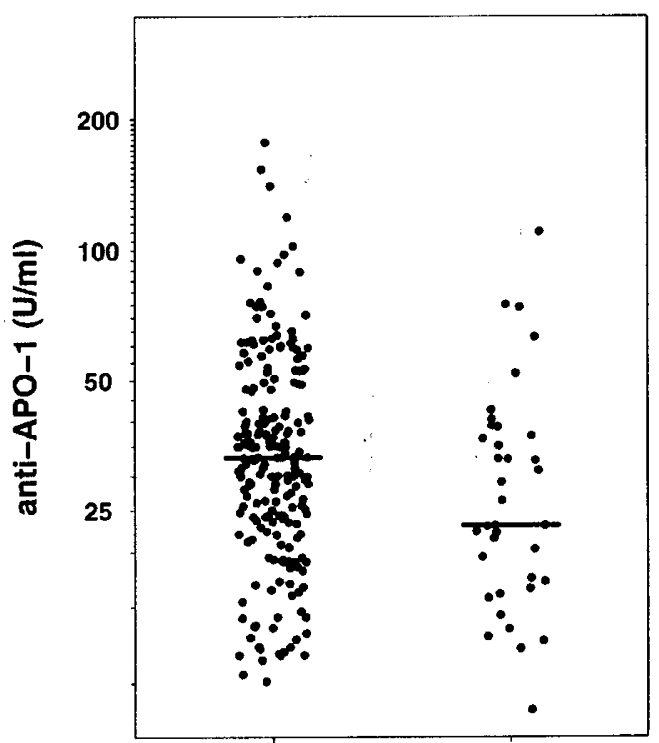

HIV +

c)

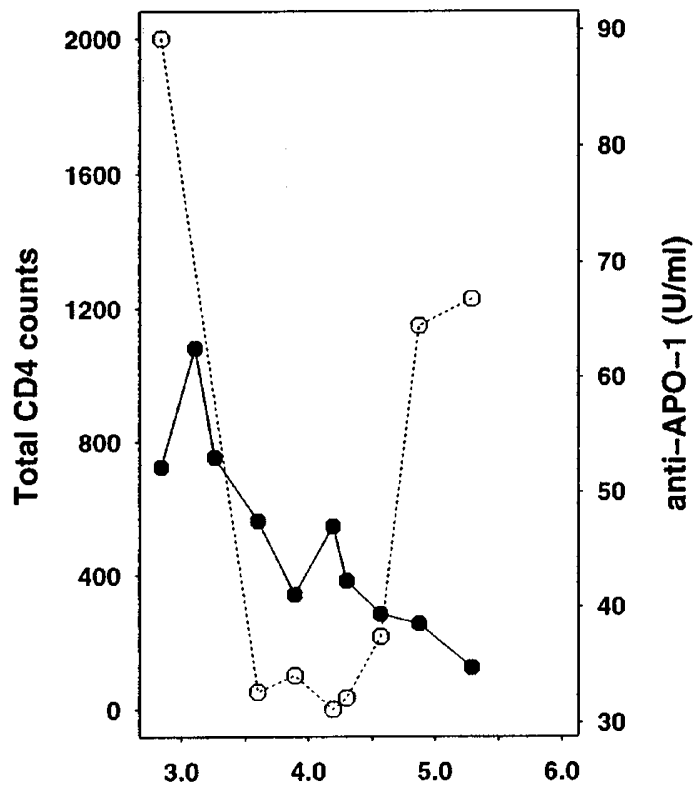

b)

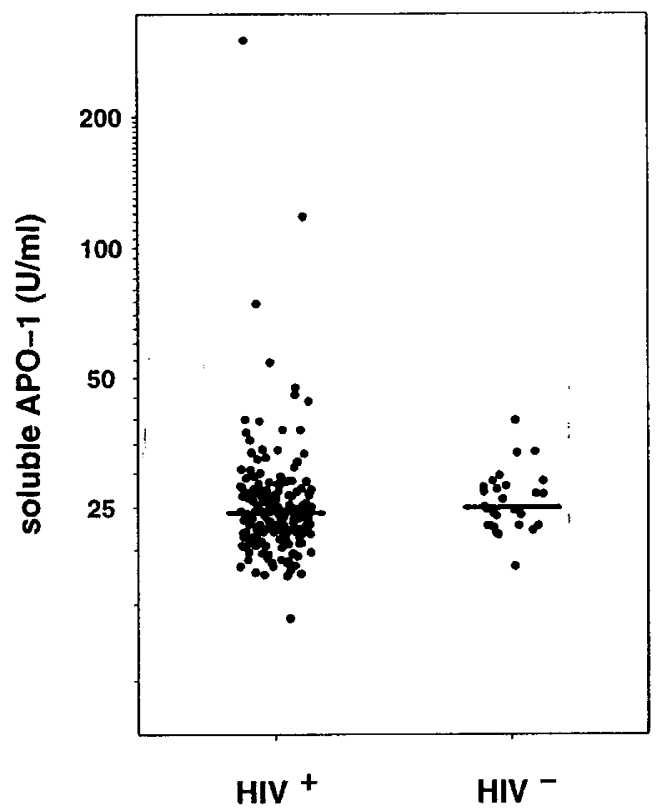

d)

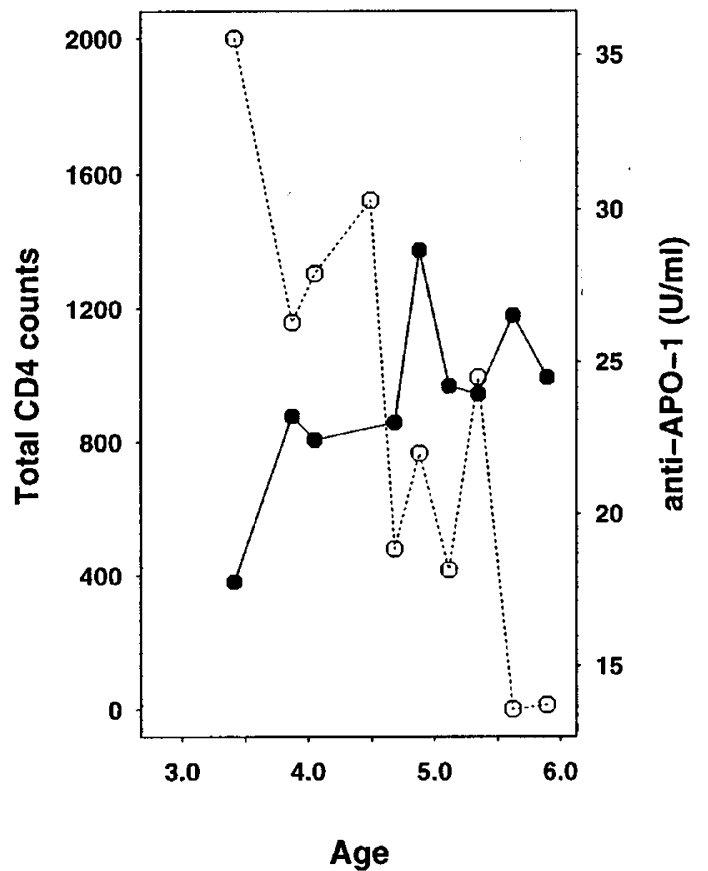

Figure 1 Anti-CD95 (APO-1/Fas) autoantibodies and SCD95 (sAPO-1/Fas) in sera from HIV-1-infected children and healthy controls. (a) Anti-CD95 autoantibody levels in patient sera (HIV-1 $\left.{ }^{+}, n=218\right)$ compared to healthy controls ( $\mathrm{HIV}^{-}, n=37$ ). Horizontal bars indicate the median of anti-CD95 concentrations for the respective group. (b) Soluble CD95 levels in patient sera (HIV-1 $\left.{ }^{+}, n=178\right)$ compared to healthy controls $\left(\mathrm{HIV}^{-}, n=28\right)$. Horizontal bars indicate the median of sCD95 concentrations for the respective group. (c) Repeated measurements of anti-CD95 autoantibodies $(O)$ and absolute CD4 ${ }^{+} \mathrm{T}$ cell counts $(\mathbf{O})$ in a patient with rapid disease progression despite therapy with zidovudine (AZT). A steady increase in anti-CD95 autoantibody levels was seen at CD4 ${ }^{+} \mathrm{T}_{\text {cell }}$ counts below 500 cells/ $\mu$ l. (d) Longitudinal data of a long-term non-progressor with slight increase in absolute CD4 ${ }^{+} \mathrm{T}$ cell counts $(\mathbf{O})$ and slightly decreasing serum levels of antiCD95 autoantibodies $(O)$ following start of antiretroviral treatment with AZT 


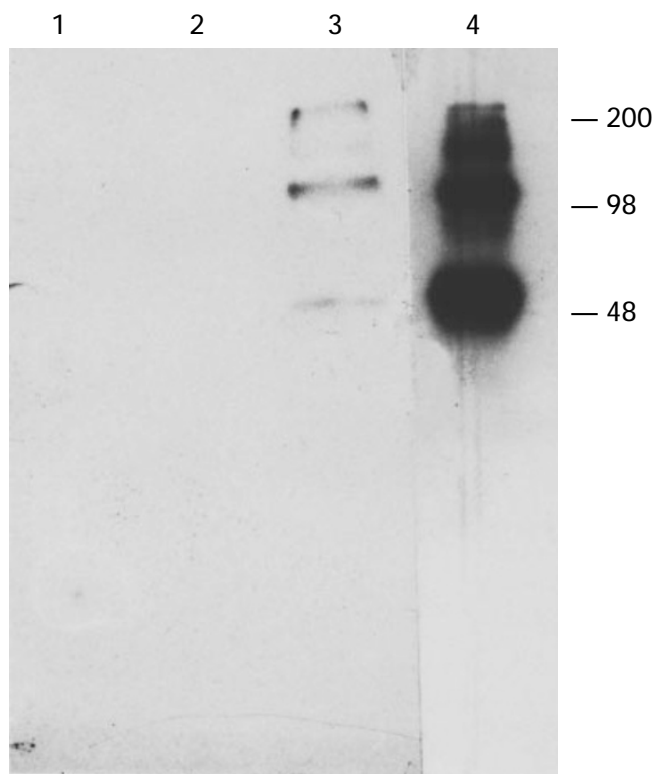

Figure 2 Western blot analysis of anti-CD95 in sera from HIV-1-infected children. Lanes 1-4: Purified recombinant CD95 (2 $\mu \mathrm{g} / \mathrm{lane})$ was run on a $12 \%$ SDS-PAGE under nonreducing conditions. CD95 was transfered onto nitrocellulose membranes by electroblotting. Lane 1 was incubated with culture medium. Lane 2 was incubated with serum from a HIV ${ }^{-}$donor (ELISA negative). In lane 3 recombinant CD95 was detected by anti-CD95 autoantibodies present in a representative serum sample from an HIV-1. infected individual (ELISA positive, $100 \mathrm{U} / \mathrm{ml}$ ). In lane 4 recombinant CD95 was detected by the humanized anti-CD95 antibody $(10 \mu \mathrm{g} / \mathrm{ml})$. Subsequently, antibodies specific for CD95 were detected with a goat anti-human HRPOconjugated IgG $F\left(a b^{\prime}\right)_{2}$-fragment. The enzyme reaction was performed using the ECL chemoluminescence method

3a), indicating no direct influence of B cell expansion on the level of anti-CD95 autoantibodies. Furthermore, a negative correlation between anti-CD95 autoantibody level and Ig levels was found (Figure 3b). These data indicate that high levels of anti-CD95 autoantibodies are not a direct consequence of global B cell stimulation during HIV-1 infection.

\section{Correlation of increased CD95-expression with $\mathrm{CD}^{+}{ }^{+} \mathrm{T}$ cell depletion}

In children perinatally infected with HIV-1 a progressive depletion of $\mathrm{CD}^{+} \mathrm{T}$ cells was found with increasing age $(r=-0.58, P<0.001)$. Figure $4 a$ shows this linear agedependent decrease of $\mathrm{CD} 4^{+} \mathrm{T}$ cell counts in comparison to the lowest numbers of $\mathrm{CD}^{+} \mathrm{T}$ cells associated with normal immune function in these patients (dashed line). In contrast, numbers of $\mathrm{CD}^{+} \mathrm{T}$ cells remained within the normal range (dashed line, Figure 4b). We recently described an upregulation of CD95-expression in both $\mathrm{CD} 4^{+}$and $\mathrm{CD} 8^{+} \mathrm{T}$ cells of $\mathrm{HIV}-1^{+}$children (Debatin et al, 1994). Detailed analysis of these data revealed an age-dependent increase in CD95-expression in $\mathrm{CD}^{+}(r=0.47, P=0.003$; Figure 4c) and $\mathrm{CD}^{+} \mathrm{T}$ cells $(r=0.31, P=0.049$; Figure $4 \mathrm{~d})$. When $\mathrm{CD}^{+} 5^{+} \mathrm{T}$ cells were analyzed with respect to total $\mathrm{T}$ cell numbers, a strong correlation was found between depletion of $\mathrm{CD}^{+} \mathrm{T}$ cells in vivo and the increase in CD95-expression $(r=-0.81, P<0.001$; Figure $4 \mathrm{e})$. In contrast, such a a)

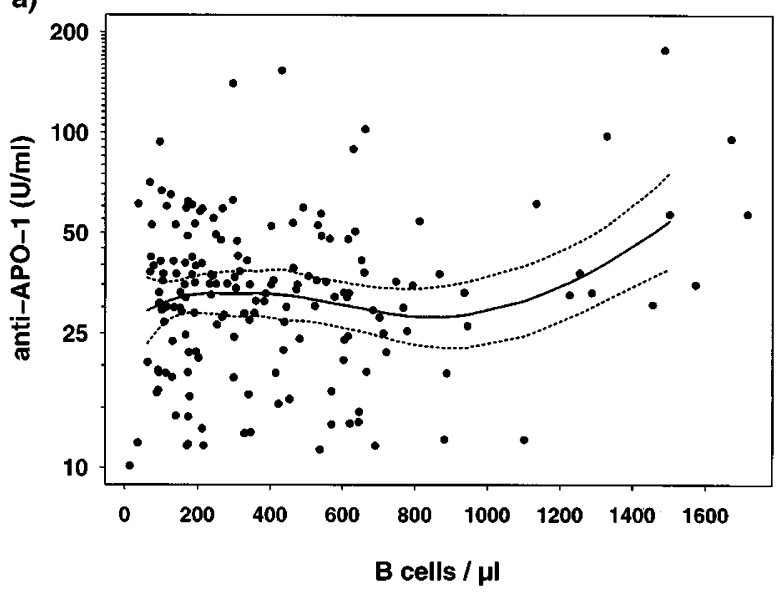

b)

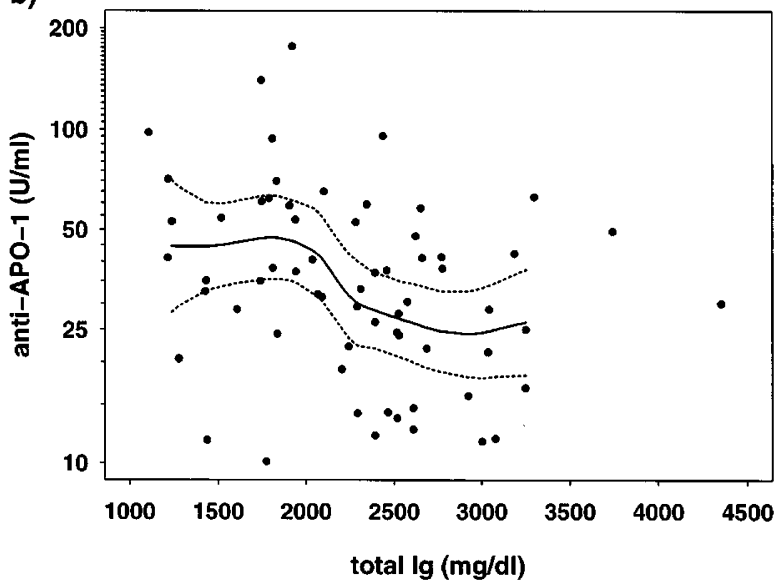

Figure 3 Univariate analysis of anti-CD95 concentration and total number of $B$ cells or total serum immunoglobulin concentration (IgM, IgG and $\lg A$ ). Scatterplots of the observed data are superimposed by a smooth curve representing the loess fit (solid line) and pointwise 95\% confidence intervals (dotted lines). Spearman's rank correlation was additionally computed to measure the strength of the association of anti-CD95 level and either B cell numbers (a) $r=0.031 ; P=0.68$ ) or total serum Ig concentrations (b) $r=-0.31$; $P=0.014)$

correlation was not observed for $\mathrm{CD}^{+} \mathrm{T}$ cells $(r=-0.17$, $P=0.28$; Figure $4 \mathrm{f})$.

\section{Correlation of anti-CD95 autoantibody levels with $\mathrm{CD}^{+} \mathrm{T}$ cell depletion}

Multiple regression analysis was performed to evaluate parameters that may determine the level of anti-CD95 autoantibodies in sera of HIV $-1^{+}$children. We included the age of the patient, total number of lymphocytes, $\mathrm{CD}^{+}$and $\mathrm{CD}^{+} \mathrm{T}$ cell count, and total number of $\mathrm{CD}^{+} 5^{+} \mathrm{CD} 4^{+}$and $\mathrm{CD}^{+} 5^{+} \mathrm{CD}^{+} \mathrm{T}$ cells. Multiple dependencies between antiCD95-autoantibody levels and these covariates were analyzed in $\mathrm{HIV}-1^{+}$children using generalised linear models for dependent data (Liang and Zeger, 1986) applying a backward elimination procedure. The final model obtained by this approach includes the total number of $C D 4^{+} \mathrm{T}$ cells, the 
a)

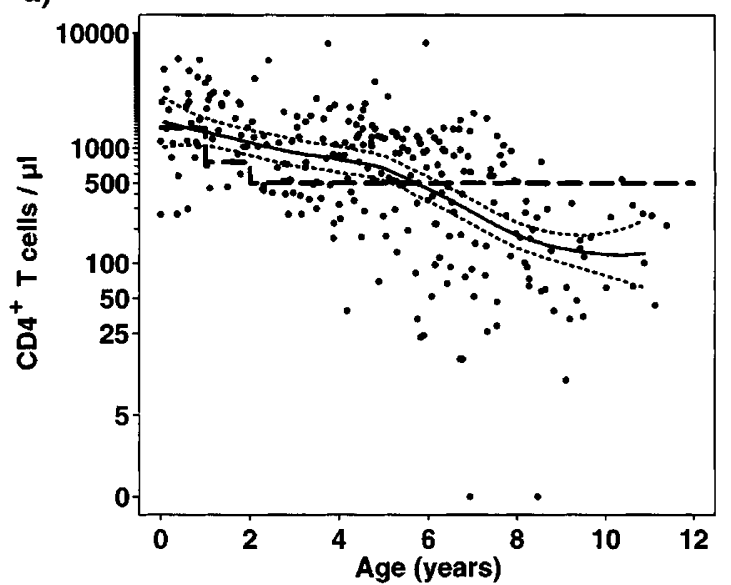

c)

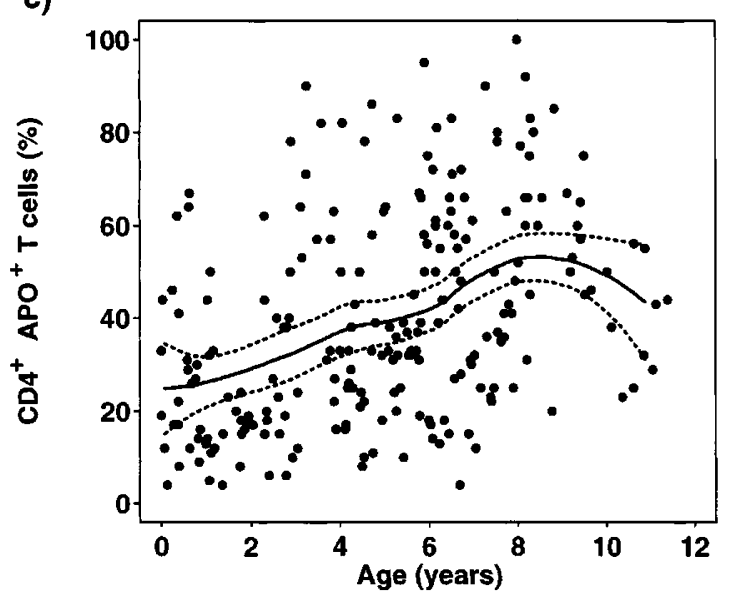

e)

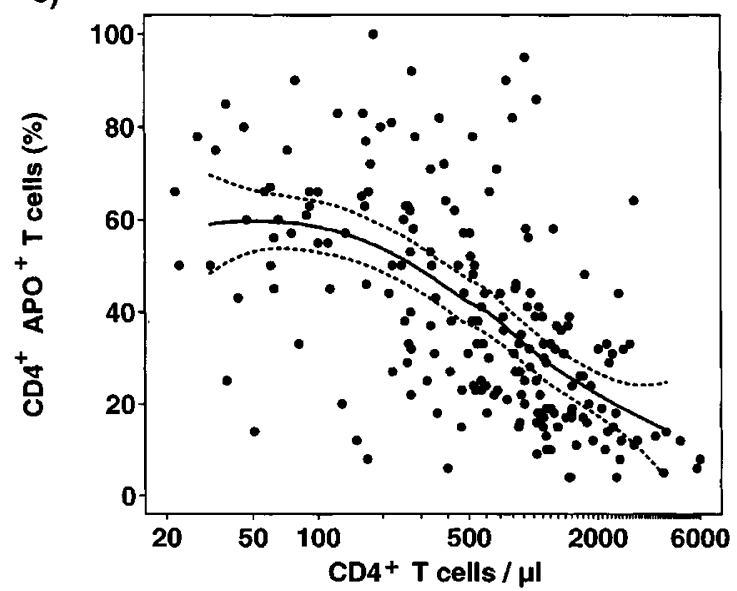

b)

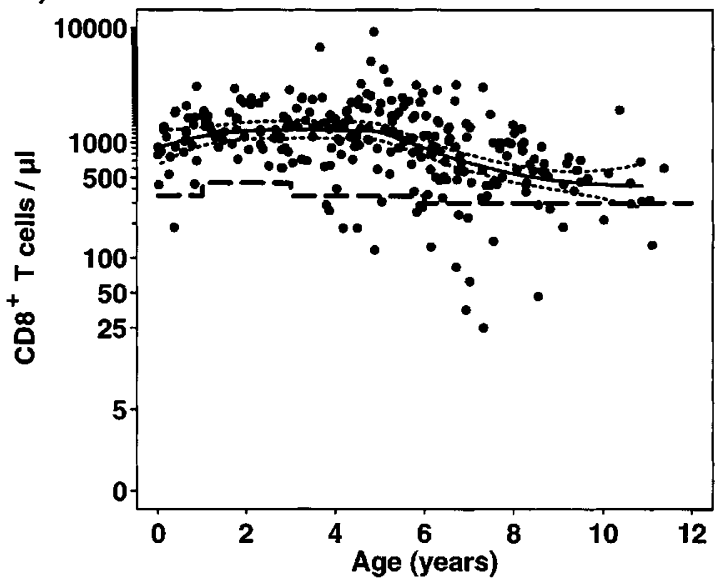

d)

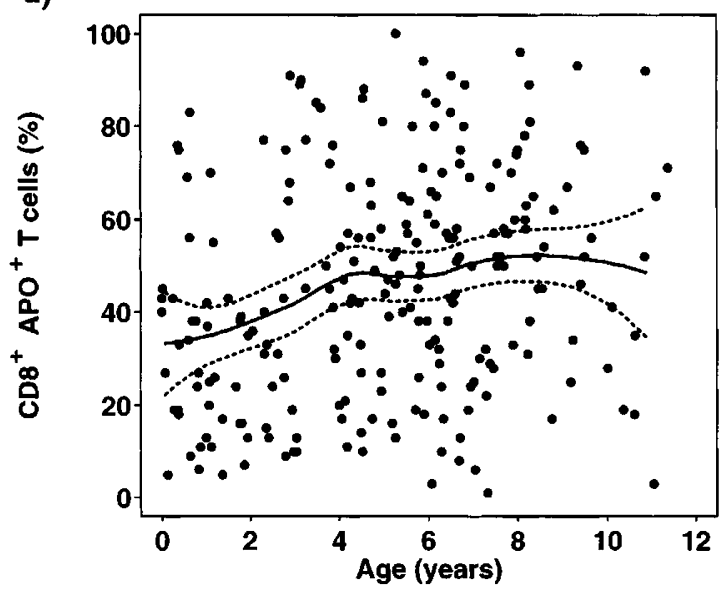

f)

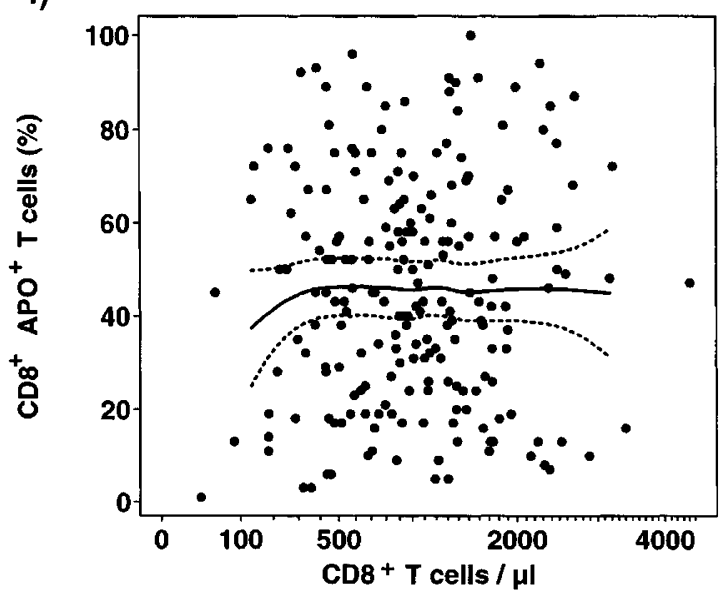

Figure 4 Correlation analysis of CD95-expression on $\mathrm{CD} 4^{+}$and $\mathrm{CD} 8^{+} \mathrm{T}$ cells with age and total numbers of $\mathrm{CD} 4^{+}$and $\mathrm{CD} 8^{+} \mathrm{T}$ cells. The correlation structure between the different variables was explored by depicting the pairwise scatterplots with corresponding loess curves (solid lines) and pointwise $95 \%$ confidence intervals (dotted lines). In $\mathbf{a}$ and $\mathbf{b}$ the data points were compared with the lower limits of absolute $\mathrm{CD} 4^{+}$and $\mathrm{CD} 8^{+} \mathrm{T}$ cell counts associated with normal immune function (dashed lines). Total numbers of $\mathrm{CD} 4^{+}$decrease with age in HIV-1 ${ }^{+}$children (a). No such relationship is seen with total numbers of CD $8^{+} \mathrm{T}$ cells and age (b). CD95-expression on $\mathrm{CD}^{+}$(c) and $\mathrm{CD} 8^{+} \mathrm{T}$ cells (d) increases with age in HIV-1 ${ }^{+}$children. The percentage of $\mathrm{CD} 95^{+} \mathrm{CD} 4^{+} \mathrm{T}$ cells increases with disease progression as indicated by decreasing numbers of total $\mathrm{CD} 4^{+} \mathrm{T}$ cells $(\mathbf{e})$. No such relationship is observed between the percentage of $\mathrm{CD} 95^{+} \mathrm{CD} 8^{+} \mathrm{T}$ cells and total numbers of $\mathrm{CD}^{+} \mathrm{T}$ cells $(\mathbf{f})$ 
total number of $\mathrm{CD}^{+} 5^{+} \mathrm{CD} 4^{+} \mathrm{T}$ cells, chronological age and interaction terms of these covariates and revealed a strong negative correlation between serum levels of anti-CD95 and absolute $\mathrm{CD}^{+} \mathrm{T}$ cell counts (Figure 5). Thus, the results of multivariate analysis of pooled data correspond to longitudinal observations in individual patients and suggest a role of antiCD95 autoantibodies in CD4 ${ }^{+}$cell depletion.

\section{Discussion}

Apoptosis in $\mathrm{CD}^{+} \mathrm{T}$ cells is considered to be an important mechanism for $\mathrm{CD}^{+} \mathrm{T}$ cell depletion during HIV-1-infection (Gougeon, 1995). In normal T cells a tight balance between survival, expansion and apoptosis is necessary to maintain homeostasis and control of immune responses. Regulation of apoptosis in peripheral T cells crucially involves the CD95 cell surface receptor and its ligand (Krammer et al, 1994). In previous studies we had observed an increased expression of CD95 and CD95-L together with an increased sensitivity towards anti-CD95- and anti-CD3-induced apoptosis in freshly isolated T cells from HIV-1-infected children (Debatin et al, 1994, Bäumler et al, 1996).

These findings were extended in the present study by measuring CD95-expression on $\mathrm{T}$ cells together with serum levels of anti-CD95 autoantibodies (as potential inducers of

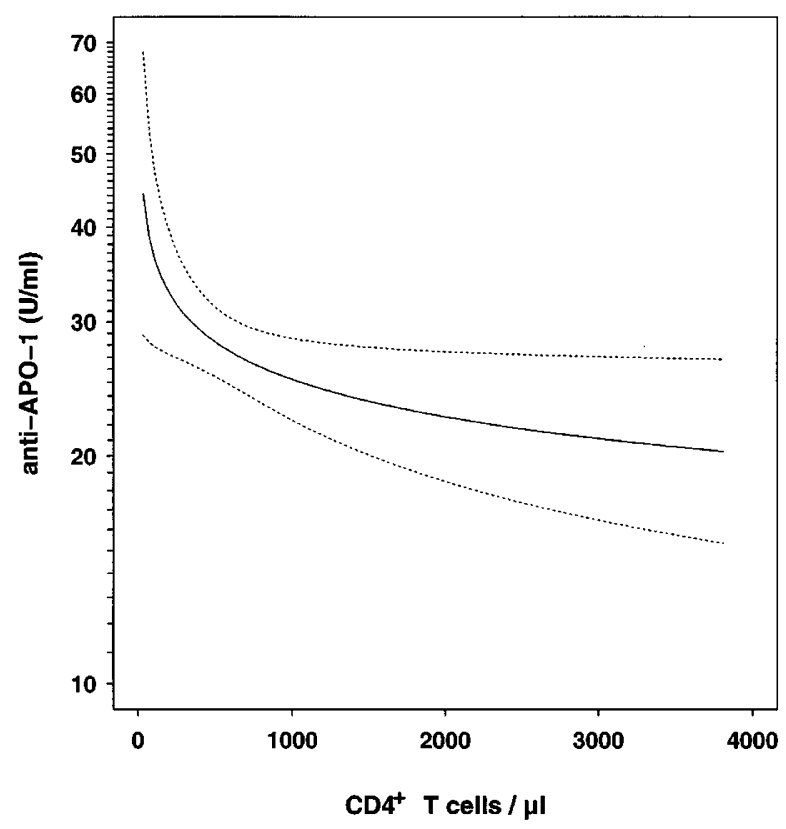

Figure 5 Multiple linear regression analysis for evaluation of parameters that determine serum levels of anti-CD95 autoantibodies in HIV-1-infected children. Statistically significant factors influencing anti-CD95 autoantibody levels were: total $\mathrm{CD} 4^{+} \mathrm{T}$ cell counts, total number of $\mathrm{CD} 95^{+} \mathrm{CD} 4^{+} \mathrm{T}$ cells, age of the patients and interaction terms between these covariates. Graphical description of the model generated by backward elimination procedures shows the partial effect plot of anti-CD95 autoantibody concentration vs total CD4 ${ }^{+} \mathrm{T}$ cell count (adjusted to the median values of total $\mathrm{CD} 95^{+} \mathrm{CD} 4^{+} \mathrm{T}$ cells and age). The solid line represents the predicted values for the anti-CD95 autoantibody concentration, the dotted lines show the pointwise 95\% confidence limits of the predicted values. The model describes that antiCD95 autoantibody levels rise steeply once absolute $\mathrm{CD}^{+} \mathrm{T}$ cell counts fall below a critical value of 500 cells $/ \mu$ l apoptosis) and SCD95 (that may counteract CD95-L function) in relation to disease progression (as indicated by decreasing $\mathrm{CD}^{+} \mathrm{T}$ cell counts) in these patients. In addition to increased expression of CD95 on the surface of both $\mathrm{CD}^{+}$and $\mathrm{CD}^{+}{ }^{+} \mathrm{T}$ cells we found increased serum levels of anti-CD95 autoantibodies, while serum levels of sCD95 were not elevated in HIV-1-infected children. Recently, increased levels of SCD95 have been found in a cohort of HIV-1-infected adults (Fadeel et al, 1997). It remains unclear whether these different findings result from differences in the patient cohorts (adults vs children) or in the methods used (different anti-CD95 antibodies for sCD95-ELISA). However, no correlation of sCD95 levels with clinical disease progression was observed in the adult patients.

In $\mathrm{HIV}-1^{+}$children, the increase of CD95-expression strongly correlated with the decline of total $\mathrm{CD}^{+} \mathrm{T}$ cell counts. Since all of these children had acquired HIV-1 perinatally from their $\mathrm{HIV}-1^{+}$mothers, the age of the patients corresponds directly to the duration of infection. Thus, expression of CD95 on the surface of $\mathrm{CD}^{+}$and $\mathrm{CD}^{+} \mathrm{T}$ cells of these patients increased also with age. In advanced stages of HIV-infection only CD95-positive CD4 ${ }^{+}$ $T$ cells were found.

In HIV-1 infection expression of CD95 is upregulated in both $\mathrm{CD}^{+}$and $\mathrm{CD}^{+}{ }^{+} \mathrm{T}$ cells. The mechanisms that lead to an increase in CD95-expression (as well as to susceptibility towards CD95-mediated apoptosis) in peripheral blood $\mathrm{T}$ cells from $\mathrm{HIV}-1^{+}$patients may involve accelerated activation and 'physiologic aging' of $\mathrm{T}$ cells (PlaegerMarshall et al, 1993; Gougeon et al, 1996). Additionally, dysregulation of the CD95 receptor/ligand system may be directed towards $\mathrm{CD}^{+} \mathrm{T}$ cells by immunomodulating HIVgene products such as Tat and gp120 (Banda et al, 1992; Finkel and Banda, 1994; Oyaizu et al, 1993; Westendorp et al, 1995). Interestingly, we could show in a small group of asymptomatic and oligosymptomatic HIV-1-infected children, that increased CD95-expression in peripheral $\mathrm{T}$ cells was due to an increased percentage of CD95-highly positive, $\mathrm{CD}_{45 \mathrm{RO}^{+}} \mathrm{CD} 4 \mathrm{RA}^{-}$primed/memory $\mathrm{CD}^{+} \mathrm{T}$ cells, which are also sensitive towards anti-CD95-induced apoptosis in vitro (Böhler et al, 1997a).

A remarkable finding in our study is the detection of autoantibodies directed against the CD95 cell surface receptor. By multivariate analysis a strong negative correlation between $\mathrm{CD}^{+} \mathrm{T}$ cell counts and the presence of anti-CD95 autoantibodies was found in particular at $\mathrm{CD}^{+} \mathrm{T}$ cell counts below 500 cells $/ \mu \mathrm{l}$. This predicted relationship was indeed confirmed by observations in individual patients that were followed longitudinally over a 2-3 year period. In a patient with rapid progressive disease an increase in anti-CD95 autoantibodies was seen together with a decrease in CD4+ T cell counts.

Development of anti-CD95 autoantibodies may be a consequence of polyclonal B cell activation and global elevation of $\mathrm{lg}$ levels observed predominantly during the early phases of HIV-1 infection (Fauci, 1988). However, we did not find a positive correlation between anti-CD95 autoantibody levels and total Ig levels in serum, total numbers of lymphocytes, $\mathrm{B}$ cells or $\mathrm{CD}^{+} \mathrm{T}$ cells or 
$\mathrm{CD}^{+} 5^{+} \mathrm{CD} 8^{+} \mathrm{T}$ cells, respectively. These findings suggest that the presence of anti-CD95 autoantibodies is not directly related to global activation of the immune system.

Autoantibodies against various cell surface molecules including HLA have been found in sera of most HIV-1 infected individuals. Some of these autoantibodies may reflect crossreactivity between antibodies against viral proteins such as gp120 and cellular proteins. HIV-1 gp120 has been found to bear sequence homology to CD95 and CD4 (Szawlowski et al, 1993; Zagury et al, 1993). The identical eight amino acid sequence shared by gp120 and CD95 may be responsible for the generation of autoantibodies that react to CD95 on the surface of CD95expressing T cells. Thus, anti-CD95 autoantibodies present in vivo may contribute to CD95-mediated T cell depletion in HIV-1 infection.

Since other autoantibodies also increase during late stages of HIV-1 infection, our observation may simply reflect an epiphenomenon of acquired immunodeficiency due to loss of functional CD4 ${ }^{+} \mathrm{T}$ cells leading to impaired control of specific antibody synthesis. However, autoantibodies directed against CD95 may be of functional importance. In advanced stages of the disease, peripheral T cells express high amounts of CD95 and CD95L and are sensitive towards CD95-mediated apoptosis (Gougeon et al, 1996; Bäumler et al, 1996, Böhler et al, 1997a, b). Anti-CD95 autoantibodies may interfere with CD95-mediated AICD in vivo either by directly inducing apoptosis in sensitive $T$ cells or by blocking CD95/CD95L interactions, thus blocking autocrine or paracrine cell death. Recently, Silvestris et al (1996) demonstrated in a cohort of HIV-1-infected adults that anti-CD95 autoantibodies purified from patients' sera were capable of inducing apoptosis in CD95-sensitive CEM lymphoblasts. Thus, anti-CD95 autoantibodies may be functional in HIV-infected individuals and may contribute to increased $T$ cell loss by causing apoptosis of uninfected $T$ cells either via pro-apoptotic signaling through the CD95receptor or by inducing antibody-dependent cytotoxic $T$ cell responses. Indeed, cytotoxic $T$ cells recognizing the peptide sequence common to CD95 and gp120 have been found in the peripheral blood of HIV-1-infected individuals (Moukrim and Achour, 1995). Thus, an immune response to HIV-1 envelope proteins might directly contribute to $\mathrm{T}$ cell depletion involving CD95-mediated apoptosis.

In conclusion, the present study provides further evidence for an involvement of the CD95 system in T cell depletion in HIV-1-infected individuals. First, CD95-expression is strongly enhanced during $\mathrm{CD}^{+} \mathrm{T}$ cell depletion. Second, anti-CD95 autoantibody levels significantly increase with progressive $\mathrm{CD}^{+} \mathrm{T}$ cell depletion. In addition, serum levels of SCD95 molecules that may counteract CD95-L function are not elevated. Increased CD95-L production and sensitivity towards CD95-induced apoptosis have previously been demonstrated in freshly isolated peripheral blood $T$ cells from our patients (Bäumler et al, 1996). Thus, in HIV-1 infection the balance between pro-apoptotic and anti-apoptotic mechanisms that critically involve the CD95 receptor/ligand system in $\mathrm{T}$ cells are disturbed and shifted towards apoptosis. It remains to be evaluated whether increased anti-CD95 autoantibodies and other parameters of hyperreactivity of the CD95 system (e.g., expression of CD95/CD95-L in T cells) may serve as a prognostic factor in $\mathrm{HIV}-1^{+}$patients.

\section{Materials and Methods}

\section{Patients}

The cohort of 44 HIV-1-infected children and 44 HIV-1-exposed but -uninfected children was part of the 'German Multicenter Study on HIV Infection in Children', supported by the Federal Ministry of Health and approved by the local Ethical Committee. Children between 1 month and 12 years of age born to HIV-1 infected mothers were eligible for the study. Parents and, when appropriate, patients gave informed consent for participation in the study. Blood samples were obtained by venipuncture in conjuction with routine laboratory investigations. Both $\mathrm{HIV}-1^{+}$patients and HIV $-1^{-}$controls were followed up at 3 month intervals until 2 years of age and at least yearly thereafter (total number of investigations: 342 in the HIV-1 $1^{+}$group and 183 in the HIV $-1^{-}$ control group). Children considered to have AIDS-related complex were treated with AZT and intravenous IgG. Controls had been repeatedly shown to be HIV-1 ${ }^{-}$as defined by negative results of HIV-1 Western blot, HIV-p24 antigen assay, and viral culture. All patients and controls or their relatives gave informed consent prior to venipuncture.

\section{ELISA for detection of anti-APO-1 autoantibodies in serum}

Purified recombinant CD95 $(2 \mu \mathrm{g} / \mathrm{ml})$ in $100 \mu \mathrm{l} \mathrm{NaHCO}_{3} \mathrm{pH} 9.6$ was coupled to ELISA plates (Falcon, Heidelberg, Germany) for $12 \mathrm{~h}$ at $4{ }^{\circ} \mathrm{C}$. Plates were washed three times with $100 \mu$ l PBS containing $0.05 \%$ Tween-20 (PBS/Tween) and blocked with $2 \%$ BSA in PBS/ Tween for $30 \mathrm{~min}$ at room temperature. After removing the BSA solution human sera were added at a 1:100 dilution in a $2.5 \%$ non-fat dry milk powder/PBS solution. Serum samples had been centrifuged for $10 \mathrm{~min}$ at $17300 \times \mathrm{g}$. After $1.5 \mathrm{~h}$ incubation plates were washed and horseradish-peroxidase (HRPO)- conjugated goat-anti human $\mathrm{IgG}^{+}$ $\operatorname{lgM~} \mathrm{F}(\mathrm{ab})_{2}$ fragment, adsorbed against bovine serum proteins (Dianova, Hamburg, Germany), was added in PBS/Tween for $1.5 \mathrm{~h}$. After another wash cycle staining was developed with $75 \mu$ substrate solution $(0.1 \%$ orthophenylendiamine in $0.05 \mathrm{M}$ citric acid, $0.1 \mathrm{M}$ $\mathrm{Na}_{2} \mathrm{HCO}_{3}$ ) for $10 \mathrm{~min}$ and the reaction was stopped by addition of $25 \mu \mathrm{l}$ $3 \mathrm{~N} \mathrm{H}_{2} \mathrm{SO}_{4}$. The results were read with an ELISA reader (EAR 400AT LAB Instruments, Grödig, Austria) at $492 \mathrm{~nm}$. For standardisation all assays were controlled with serum from healthy donors and a chimeric anti-CD95 antibody containing the human instead of the murine $\mathrm{FC}$ part. The detection limit for humanized anti-CD95 was $50 \mathrm{pg} / \mathrm{well}$ $(500 \mathrm{pg} / \mathrm{ml})$. Human sera were used at a dilution of $1: 100$. Thus, the detection limit for anti-CD95 in human sera was $5 \mathrm{ng}$. ELISA results were confirmed by detection of recombinant CD95 in a Western blot.

\section{ELISA for detection of soluble CD95 (sCD95) in serum}

The ELISA for SCD95 was used as previously described (Knipping et al, 1995) using monoclonal anti-CD95 and a rabbit polyclonal antiserum against recombinant CD95.

\section{Western blotting}

Recombinant CD95 $(2 \mu \mathrm{g} / \mathrm{ml})$ in $8 \mu$ l SDS-PAGE sample buffer was denatured for $2 \mathrm{~min}$ at $95^{\circ} \mathrm{C}$. Samples were run on a $12 \%$ SDS- 
PAGE under nonreducing conditions and transferred to nitrocellulose membranes by electroblotting $\left(1.5 \mathrm{~h}, 0.8 \mathrm{~mA} / \mathrm{cm}^{2}\right)$. Subsequently, membranes were saturated with $5 \%$ non fat dry milk powder in PBS. After 30 min blocking solution was removed and samples were added for $1.5 \mathrm{~h}$. Membranes were washed with PBS containing $0.05 \%$ Tween-20 and subsequently incubated for $1 \mathrm{~h}$ with a goat anti-human HRPO-conjugated IgG $\mathrm{F}\left(\mathrm{ab}^{\prime}\right)_{2}$-fragment (Dianova, Hamburg, Germany). Protein bands were developed using the ECL method (Amersham, Frankfurt, Germany) and light emission was detected on Kodak XAR-4 X-ray films (Kodak, Stuttgart, Germany).

\section{Immunofluorescence studies of CD95-expression on peripheral blood lymphocytes}

CD95-expression on isolated peripheral blood lymphocytes was investigated as described (Debatin et al, 1994) by staining with FITC-labelled anti-CD95 and PE-labelled anti-CD4 or anti-CD8 (Dianova, Hamburg, Germany) monoclonal antibodies and flow cytometry using a FACScan equipped with the LYSIS II software (Becton Dickinson, Heidelberg, Germany).

\section{Determination of total serum immunoglobulin}

Serum concentrations of $\lg M, \lg G$ and $\lg A$ were determined using standard procedures (nephelometry on Beckman LCS, München, Germany).

\section{Statistics}

For comparison of measurements between control and experimental groups the two-tailed Wilcoxon rank sum test was used. To describe the association between two quantitative variables a smooth curve using the loess fitting method (Cleveland and Grosse, 1991) was added to the respective scatterplot. Spearman's rank correlation coefficients $(r)$ were calculated in order to measure the strength of linear association (Lehmann, 1975). The statistical computations also include methods for repeated measurements, especially generalised regression models for dependant data (Liang and Zeger, 1986). P-values below the $5 \%$ level indicate a statistically significant result.

\section{Acknowledgements}

This work was supported by grants from 'HIV-Verbund' Heidelberg, Tumor Center Heidelberg/Mannheim and Project 'Kinderplanet'. We thank Drs S Enenkel-Stoodt, W Kreuz and A Kynast (University Children's Hospital Frankfurt, Germany) for providing patient samples and Mrs Gabi Hölzl-Wenig for expert technical assistance.

\section{References}

Alderson MR, Tough TW, Davis-Smith T, Braddy S, Falk B, Schooley KA Goodwin RG, Smith CA, Ramsdell F and Lynch DH (1995) Fas ligand mediates activation-induced cell death in human $T$ lymphocytes. J. Exp. Med. 181: 71-77

Banda NK, Bernier J, Kurahara DK, et al (1992) Cross-linking CD4 by human immunodeficiency virus gp 120 primes T cells for activation-induced apoptosis. J. Exp. Med. 176: 1099-1106

Bäumler C, Herr I, Böhler T, Benner A, Krammer PH and Debatin K-M (1996) Activation of the CD95 (APO-1/Fas) system in T cells from human immunodeficiency virus type-1 infected children. Blood 88: 1741-1746
Blackburn R, Clerici M, Mann D, et al (1991) Common sequence in HIV 1 GP41 and HLA class II beta chains can generate crossreactive autoantibodies with immunosuppressive potential early in the course of HIV 1 infection. Adv. Exp. Med. Biol. 303: 63-69

Böhler T, Nedel S, Debatin K-M (1997a) CD95-induced apoptosis contributes to loss of primed/memory but not resting/naive $T$ cells in children with human immunodeficiency virus type 1. Pediatr. Res. 41: 878-885

Böhler T, Bäumler C, Herr I, Gross A, Kurz M and Debatin K-M (1997b) Activation of the CD95-system increases with disease progression in human immunodeficiency virus type-1-infected children and adolescents. Pediatr. Infect. Dis. J. 16: $754-759$

Cheng J, Zhou T, Liu C, et al (1994) Protection from Fas-mediated apoptosis by a soluble form of the Fas molecule. Science 263: 1759-1762

Cleveland WS, Gross E (1991) Computational methods for local regression. Statistics and Computing 1: 47-62

Debatin K-M, Fahrig-Faissner A, Enenkel-StoodtS, Kreuz W, Benner A and Krammer PH (1994) High expression of APO-1 (CD95) on T lymphocytes from HIV-1 infected children. Blood 154: 3101-3103

Dhein J, Walczak H, Bäumler C, Debatin K-M and Krammer PH (1995) APO-1 mediated T cell receptor induced suicide. Nature 373: 438-441

Estaquier J, Idziorek T, Zou W, Emilie D, Farber CM, Bourez JM and Ameisen JC (1995) T helper type 1/T helper type 2 cytokines and T cell death: preventive effect of interleukin 12 on activation-induced and CD95 (Fas/APO-1)-mediated apoptosis of $\mathrm{CD}^{4+} \mathrm{T}$ cells from human immunodeficiency virus-infected persons. J. Exp. Med. 182: 1759-1767

FadeelB, Samuelsson A, Hachiya T, Broström C and Chiodi F(1997)Elevated serum levels of soluble Fas/APO-1 in human immunodeficiency virus-infected individuals. Blood 89: 4727-4730

Katsikis PD, Wunderlich ES, Smith CA, Herzenberg LA and Herzenberg LA (1995) Fas antigen stimulation induces marked apoptosis of T lymphocytes in Human Immunodeficiency Virus infected individuals. J. Exp. Med. 181: $2029-2036$

Fauci AS (1988) The human immunodeficiency virus: infectivity and mechanisms of pathogenesis. Science 239: 617-622

Finkel TH and Banda NK (1994) Indirect mechanisms of HIV pathogenesis: how does HIV kill T cells? Curr. Opin. Immunol. 6: 605-615

Finkel TH, Tudor-Williams G, Banda NK, Cotton MF, Curiel T, Monks C, Baba TW Ruprecht RM and Kupfer A (1995) Apoptosis occurs predominantly in bystander cells and not in productively infected cells of HIV-and SIV-infected lymph nodes. Nature Med. 1: 129-134

Golding H, Robey FA, Gates FT, et al (1988) Identification of homologous regions in human immunodeficiency virus I gp41 and human MHC class II beta 1 domain. I. Monoclonal antibodies against the gp41-derived peptide and patients' sera react with native HLA class II antigens, suggesting a role for autoimmunity in the pathogenesis of acquired immune deficiency syndrome. J. Exp. Med. 167:914923

Gougeon ML (1995) Does apoptosis contribute to CD4 T cell depletion in human immunodeficiency virus infection? Cell Death Differ. 2: 1-8

Gougeon ML, Lecoeur H, Duilioust A, Enouf M-G, Crouvoisier M, Goujard C, Debord T and Montagnier $L$ (1996) Programmed cell death in peripheral lymphocytes from HIV-infected persons. Increased susceptibility to apoptosis of CD4 and CD8 T cells correlates with lymphocyte activation and with disease progression. J. Immunol. 156: 3509-3520

GrouxH, Torpier G, Monte D, Mouton Y, Capron A and Ameisen JC (1992) Activationinduced death by apoptosis in $\mathrm{CD}^{+} \mathrm{T}$ cells from human immunodeficiency virusinfected asymptomatic individuals. J. Exp. Med. 175: 331-340

Itoh N, Yonehara S, Ishii A, et al (1991) The polypeptide encoded by the cDNA for human cell surface antigen Fas can mediate apoptosis. Cell 66: 233243

Ju ST, Panka DJ, Cui H, Ettinger R, el-Khatib M, SheerDH, Stanger BZ and MarshakRothstein A (1995) Fas(CD95)/FasL interactions required for programmed cell death after T-cell activation. Nature 373: 444-448

Klas C, Debatin KM, Jonker RR and Krammer PH (1993) Activation interferes with the APO-1 pathway in mature human T cells. Int. Immunol. 5: 625-630

Knipping E, Debatin K-M, Stricker K, Heilig B, Eder A and Krammer PH (1995) Identification of soluble APO- 1 in supernatants of human $B$ and $T$ cell lines and increased serum levels in B and T cell leukemias. Blood 85: 1562 - 1569

Krammer PH, Dhein J, WalczakH, et al (1994) The role of APO-1 mediated apoptosis in the immune system. Immunol. Rev. 142:175-191 
Lane HC, Depper JM, Greene WC, Whalen G, Waldmann TA and Fauci AS (1985) Qualitative analysis of immune function in patients with the acquired immunodeficiency syndrome. Evidence for a selective defect in soluble antigen recognition. N. Engl. J. Med. 313: 79-84

Lehmann EL (1975) Nonparametrics: Statistical methods based on ranks. (San Francisco: Holden and Day)

Liang KY and Zeger SL (1986) Longitudinal data analysis using generalized linear models. Biometrika 73: 13-22

Meyaard L, Otto SA, Jonker RR, Mijnster MJ, Keet RP and Miedema F (1992) Programmed death of T cells in HIV-1 infection. Science 257: 217-219

Miyawaki T, Uehara T, Nibu R, et al (1992) Differential expression of apoptosisrelated Fas antigen on lymphocyte subpopulations in human peripheral blood. J. Immunol. 149: 3753-3758

Moukrim Z and Achour A (1995) Cytotoxic T lymphocytes specific for the synthetic veinctr peptide, a sequence found within the Fas molecule and anv gp120 in the blood of HIV-1 seropositive individuals. Cell Mol. Biol. 41: 439-444

Muller S, Richalet $P$, Laurent Crawford A, et al (1992) Autoantibodies typical of nonorgan-specific autoimmune diseases in HIV-seropositive patients. AIDS 6: 933-942

Oehm A, Behrmann I, Falk W et al (1992) Purification and molecular cloning of the APO-1 cell surface antigen, a member of the tumor necrosis factor/nerve growth factor receptor superfamily. Sequence identity with the Fas antigen. J. Biol. Chem. 267: 10709-10715

Oyaizu N and Pahwa S (1995) Role of apoptosis in HIV disease pathogenesis. J. Clin. Immunol. 15: 217-231

Oyaizu N, McCloskey TW, Coronesi M, Chirmule N, Kalyanaraman VS and Pahwa S (1993) Accelerated apoptosis in peripheral blood mononuclear cells (PBMCs) from human immunodeficiency virus type- 1 infected patients and in CD4 crosslinked PBMCs from normal individuals. Blood 82: $3392-3400$
Oyaizu N, McCloskey TW, Than S, Hu R, Kalyanaraman VS and Pahwa S (1994) Cross-linking of CD4 molecules upregulates Fas antigen expression in lymphocytes by inducing Interferon- $\gamma$ and Tumor Necrosis Factor- $\alpha$ secretion. Blood 84: 2622-2631

Plaeger-Marshall S, Hultin P, Bertolli J, O'Rourke S, Kobayashi R, Kobayashi AL, Giorgi JV, Bryson Y and StiehmER(1993) Activation and differentiation antigens on T cells of healthy, at-risk, and HIV-infected children. J. Acquir. Immune Defic. Syndr. 6: 984-993

Silvestris F, Nagata S, Cafforio P, Silvestris N and Dammacco F (1996) Cross-linking of Fas by antibodies to a peculiar domain of gp120 V3 loop can enhance T cell apoptosis in HIV-1-infected patients. J. Exp. Med. 184: 2287-2300

Szawlowski PW, Hanke T and Randall RE (1993) Sequence homology between HIV$1 \mathrm{gp} 120$ and the apoptosis mediating protein Fas. AIDS 7: 1018

Trauth BC, Klas C, Peters AM, et al (1989) Monoclonal antibody-mediated tumor regression by induction of apoptosis. Science 245: 301-305

Via CS, Shearer GM (1989) Autoimmunity and the acquired immune deficiency syndrome. Curr. Opin. Immunol. 1: 753-756

Westendorp MO, Frank R, Ochsenbauer C, Stricker K, Dhein J, Walczak H, Debatin KM and Krammer PH (1995) The mechanism of HIV Tat and gp120-sensitized T cell apoptosis. Nature 375: 497-500

Yonehara S, Ishii A and Yonehara M (1989) A cell-killing monoclonal antibody (antiFas) to a cell surface antigen co-downregulated with the receptor of tumor necrosis factor. J. Exp. Med. 169: 1747-1756

Zagury JF, Bernard J, Achour A, et al (1993) Identification of CD4 and major histocompatibility complex functional peptide sites and their homology with oligopeptides from human immunodeficiency virus type 1 glycoprotein gp120: role in AIDS pathogenesis. Proc. Natl. Acad. Sci. USA 90:7573-7577 